\title{
Effect of Matrix Acidizing on The Performance of Selected Niger Delta Reservoirs
}

\author{
Oguamah Ifeanyi ${ }^{1, *}$, Ogunkunle Temitope ${ }^{2}$, Oseh Jeffrey ${ }^{3}$ \\ ${ }^{1}$ Department of Petroleum Engineering, Federal University of Technology, Owerri, Nigeria \\ ${ }^{2}$ Department of Petroleum Engineering, Madonna University, Anambra, Nigeria \\ ${ }^{3}$ Dept. of Chemical and Petroleum Engineering, Afe Babalola University, Ado Ekiti, Nigeria \\ Email address: \\ uchelex@gmail.com (O. Ifeanyi), fredtopy@yahoo.com.com (O. Temitope), jeffreydengr@gmail.com (O. Jeffrey)
}

\section{To cite this article:}

Oguamah Ifeanyi, Ogunkunle Temitope, Oseh Jeffrey. Effect of Matrix Acidizing on The Performance of Selected Niger Delta Reservoirs. International Journal of Oil, Gas and Coal Engineering. Vol. 3, No. 2, 2015, pp. 18-23. doi: 10.11648/j.ogce.20150302.11

\begin{abstract}
The performance of matrix acidized selected wells from the Tertiary sandstone reservoirs in the Niger/Delta was evaluated, Data obtained was used to evaluate flow efficiency and production performance before and after acidizing. The results showed that Matrix acidizing proven to be the best stimulation technique employed in recent years to remove near wellbore damages and invariably increase productivity. The analysis involves the post net oil and percentage increase in oil achieved after acidizing, well inflow performance quality indicator and decline rate analysis.
\end{abstract}

Keywords: Matrix Acidizing, Wellbore Damage, Well Stimulation

\section{Introduction}

Acidizing is a chemical stimulation technique which involves the injection of an acid solution at pressure below the fracture pressure of the formation to enable improved production by eliminating the formation damage [1]. Acid treatment involves pumping highly pressurized acid into the well, thereby dissolving sediments to improve permeability. This process forms channels through which the hydrocarbons may flow [2]. The most common acid employed to stimulate production is Hydrochloric (HCL) which is useful in removing calcite materials from reservoirs and widely used in carbonate acidizing [3]. Hydrochloric acid may be combined with Hydrofluoric acid (HF) which dissolves silicate phases from the reservoir rocks [4], and Acetic acid also shows better results in carbonate reservoirs [5]

The technical objectives of well stimulation are to remove, reduce, or bypass the formation damage, reduce sand production and clean up the perforation [6]. Formation damage which can be as a result of drilling, completion or production operations in the well can be of three types (a) Absolute permeability damage: The particulate materials block the formation pore spaces thereby reducing permeability [7]; Relative permeability changes which results in an adverse relative permeability effect in highly water saturated zone, thereby creating significant reduction in the apparent relative permeability to oil [8] and viscosity effect due to rock mineral alterations [9]. The economic objectives are to increase flow rate and optimize production from the reservoir. Stimulation candidate selection or identification is the process of recognizing and selecting wells that have potential for higher production and better return on investment after the treatment. Selection of the optimum size of a stimulation treatment is based primarily on economics, but the candidate selection process must consider the stimulation budget, treatment cost, initial increase in production rate, additional reserves that may be produced before the well reaches its economic limit, rate of production decline before and after stimulation and also reservoir and mechanical problems that could make the treatment to be unsuccessful. Several techniques for selecting stimulation candidates exist in literature and also in the industry. [10] [11] [12] [13]

It is important to consider damage mechanisms when designing a matrix treatment, as dissolving calcites, quartz, or clay minerals may affect the reservoir differently [14]. A limited number of studies have quantified the effect of HCL matrix acidizing on recoverability and physical properties of formations [15]. However, less is known about the development of conductivity and the concentrations necessary to optimize conductivity and by extension, the impact on 
production and rock stability.

Successful acidizing begins with recognizing a viable candidate, also matrix acidizing with the appropriate system in correctly Identified candidate well is the most cost efficient way to enhance oil production in sandstone and carbonate reservoirs [16]. Wells that have skin damage are good candidate for well stimulation treatment, major increase in productivity or injectivity can result. The well and the treatment however, should be selected with care and reservoir conditions should be adequate to assure economic payout. Misapplied stimulation treatments are costly and ineffective, often creating more problems than they solve. Simplified to series of questions, the following is process for recognizing a viable acidizing candidate. Selecting the correct treatment is often not simple. With an engineering approach to any well problem however, the chance of success is generally increased. The following information should be considered in the selection of a well treatment.

\section{Methodology}

In this study, the performance of matrix acidization for some selected wells from the Tertiary sandstone reservoirs in the Niger/Delta was evaluated. Data obtained was used to evaluate flow efficiency and production performance before and after acidizing.

Evaluating well performance after acid treatment is critical in determining the performance of matrix acid treatment and its further future application in the Niger/Delta for near wellbore formation damage removal. Some of the useful well performance indicators considered include(s)

\subsection{Productivity Index (PI)}

The productivity index is a valuable tool for predicting the future performance of wells and determining if the well has become damaged due to completion. The productivity of an oil well is quantified by the productivity Index (J) [17]

$$
J=\frac{q}{p_{r}-p_{w f}}
$$

In general, the PI will remain constant over a range of production rates, i.e. the IPR will be a straight line as long as the flowing bottom-hole pressure $\mathrm{P}_{\mathrm{wf}}$ is greater than the bubble point pressure $\left(\mathrm{P}_{\mathrm{b}}\right)$. Below $\mathrm{P}_{\mathrm{b}}$, the inflow performance relationship will become a curve and rate dependent.

\subsection{Well Inflow Quality Indicator (WIQI)}

The well inflow quality indicator (WIQI) is another relative index for deciding the efficiency with which a well has been drilled and completed. This is defined as the ratio of the actual productivity index of a well to its productivity index if there were no skin. It is a diagnostic parameter which gives an indication of how good a well was completed (initially, after work over, recompletion or stimulation). This is obtained by carrying out BHP survey immediately after completion or re-entry. The well inflow quality indicator is determined by comparing PI actual to PI Ideal. WIQI measures how good a well is producing [18]

$$
W I Q I=\frac{P I_{\text {actual }}}{P I_{\text {ideal }}}
$$

Where the PI actual and PI ideal for a steady-state radial flow system are defined as shown below.

$$
\begin{gathered}
P I_{\text {actual }}=\frac{7.08 * 10^{-3} \mathrm{KH}}{\mu \beta \ln \left(\frac{r e}{r_{w}}\right)} \\
P I_{\text {Ideal }}=\frac{7.08 * 10^{-3} \mathrm{KH}}{\mu \beta \ln \left(\frac{r e}{r_{w}}\right)+S_{c}}
\end{gathered}
$$

$$
\begin{aligned}
& \mathrm{Q}=\text { Production rate }(\mathrm{stb} / \mathrm{d}) \\
& \mathrm{Pr}=\text { Reservoir Pressure }(\mathrm{psi}) \\
& \mathrm{Pwf}=\text { Well flowing Pressure }(\mathrm{psi}) \\
& \mathrm{K}=\text { Permeability }(\mathrm{mD}) \\
& \mathrm{Dp}=\text { Draw down }(\mathrm{psi}) \\
& \mu=\text { Viscosity }(\mathrm{cP}) \\
& \mathrm{B}=\text { Formation volume Factor }(\mathrm{rb} / \mathrm{Stb}) \\
& \mathrm{Re}=\text { Reservoir radius }(\mathrm{ft}) \\
& \mathrm{R}_{\mathrm{w}}=\text { Well Radius }(\mathrm{ft}) \\
& \mathrm{S}_{\mathrm{c}}=\text { Completion Skin. }
\end{aligned}
$$

The productivity of an oil well is quantified by the productivity index. In general, the PI will remain constant over a range of production rates, i.e. the IPR will be a straight line as long as the flowing bottom-hole pressure $\mathrm{P}_{\mathrm{wf}}$ is greater than the bubble point pressure $\left(\mathrm{P}_{\mathrm{b}}\right)$. Below $\mathrm{P}_{\mathrm{b}}$, the inflow performance relationship will become a curve and rate dependent.

\subsection{Decline Rate}

The decline rate of production can be defined as a decay constant of any production unit. It is the rate which production drops across a specific time period, probably in days, months or in years. The decline rate of a well indicates how good a sand control completion technique is performing over some period of time. In this work, an exponential decline pattern is assumed and used to calculate the decline rate for the each well. The exponential decline is defined as:

$$
\begin{aligned}
\frac{d q}{d t} & =\alpha q_{i} \\
q_{t} & =q_{i} e^{t}
\end{aligned}
$$

Whereas, the annual effective decline rate is given as

$$
\begin{array}{r}
B=\left[\frac{q_{t}-q_{t}-1}{q_{t}}\right] \\
B=1-e^{-\alpha}
\end{array}
$$


Where qi $=$ Initial production rate

$\mathrm{q} t=$ Production at time $(\mathrm{t})$

$\mathrm{t}=$ time $($ years $)$

$\alpha=$ Instantaneous decline

\section{Result and Discussion}

A total of nine field representative wells from three fields were investigated for the performance of acid treatment. The analysis involves the post net oil and percentage increase in oil achieved after acidizing, well inflow performance quality indicator and decline rate analysis.

Major oil producing zones in the Niger/Delta are from sandstones deposited from Tertiary sediments. Matrix acidizing has proven to be the best stimulation technique employed in recent years to remove near wellbore damages and invariably increase productivity, this is evidenced in the performance results discussed in Appendix I-II. The analysis involves the post net oil and percentage increase in oil achieved after acidizing, well inflow performance quality indicator and decline rate analysis. The chart showed an improvement in well performance after acid treatment, the production efficiency was determined using WIQI, well 8T and A585 showed a very high net oil production after treatment, while A395 showed slight improvement due to heavy formation damage. Production data following the acid treatment also showed a gradual increase in Net oil produced Table 4.5. The results shows increase in well head pressure from 1015psi - 1290psi as February. For Ekulama 355 and 345 wells, percentage increase in oil produced from 171 BOPD - 845 BOPD and 402 BOPD - 577 BOPD respectively was achieved prior and after the acid treatment. This finding shows an average of $61.6 \%$ increase in produced oil for the two wells after matrix acidizing.

This increase in oil demonstrates that the acid treatment effectively worked for removing near wellbore damage around the wells. Figure 3 and Figures 6 for the Agbada wells, also the flow efficiency WIQI improved considerably and later declined in an acceptable manner for the mentioned wells Figures 4\&6. It was observed that some candidate wells, Cases 2, 3 and 7 were no longer producing prior to the acid job Table 4.3 , but upon treatment these wells started delivering and averaged about 830 BOPD between then after acid treatment.

Generally, the main consideration for a technical success in acid job is the reduction in skin when it has been already established that the low or no production is due to skin damage. However, while some wells do react quickly, other show slower behavior. This different behavior can be seen even with wells in the same field due to variation in mineralogy around the pore throat and wettability preferences (Table 4.3). The acid treatment increase quartz solubility by improving the adsorption capability of hydrofluoric acid on sand grain surfaces and by strongly chelating silica salts thus holding more silica in solution. The built in anionic charge on the acid makes the formation sandstone water wets, this property makes it easier for oil and gas to flow through the formation to the wellbore.

\section{Conclusion}

Sandstones are known to be one of the major reservoir rocks and host almost $40 \%$ of the world known hydrocarbon reserves. Most of which requires treatment either upon primary completion or later in the life of the well due to formation damage. Matrix acidizing is a well stimulation technique which removes damages to the well through the dissolving power of an injected acid.

Matrix acid treatment has proved to be efficient in opening up blocked pores and improving permeability in the near wellbore region, therefore, increases productivity of the well. This is evident in the post treatment performance of the candidate wells treated with acid in the Niger/ Delta. The efficiency of the high penetration and dissolving capacity of both HCL and Mud acid was shown in the percentage increase in Net oil produced (about 212\%) for Ekulama wells after acid treatment. Therefore, sandstone acid is a patented acid system for moderate to deep penetrating matrix acidizing in sandstone formation.

In summary, matrix acid treatment is effective for:

- Damage Removal

- Near wellbore Stimulation

- Clean up of Gravel packs

- Acid fracturing

And the principal benefits include:

- Deep penetration of live HF

- Genuine matrix stimulation

- Large increase in fluid volume without deconsolidation

- Reduced corrosion inhibitor loading

- Safer handling

\section{Recommendation}

Unless the exact mineralogy of a formation is known, acidizing with HF acid is always a risky proposition. Carbonates, clays and iron compounds can ruin an otherwise well planned and executed treatment. Therefore, it is recommended that:

- Before acid treatment, the exact mineralogy of a formation should be known (Compatibility Test).

- Formation wettability preference should be known (Wettability Test).

- Recommended additives should be added to the acid to control/prevent corrosion and formation of emulsions (Emulsion Test). 


\section{Appendix I}

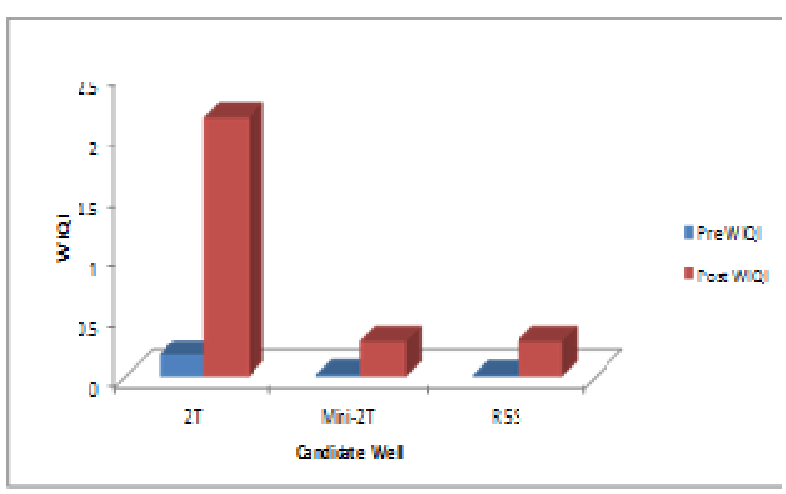

Figure 1. Well inflow quality indicator before and after acid treatment.

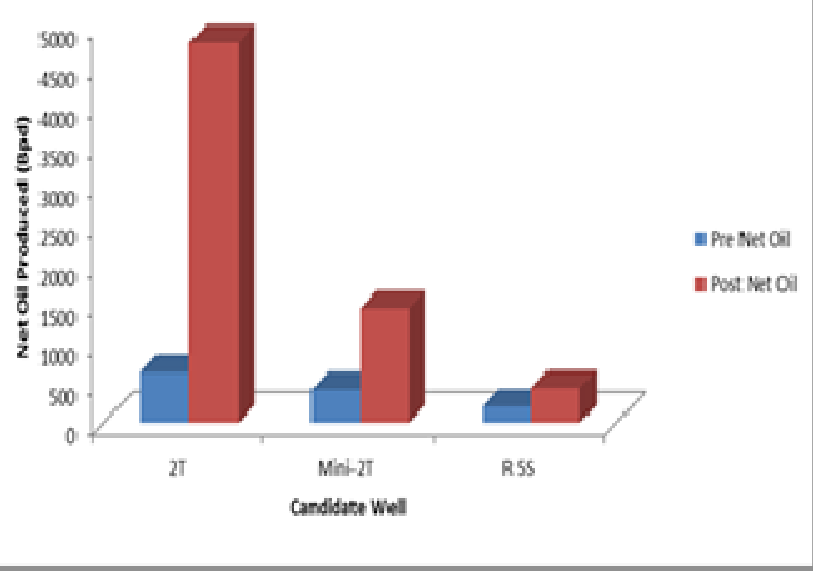

Figure 2. Net Oil produced before and after acid treatment.

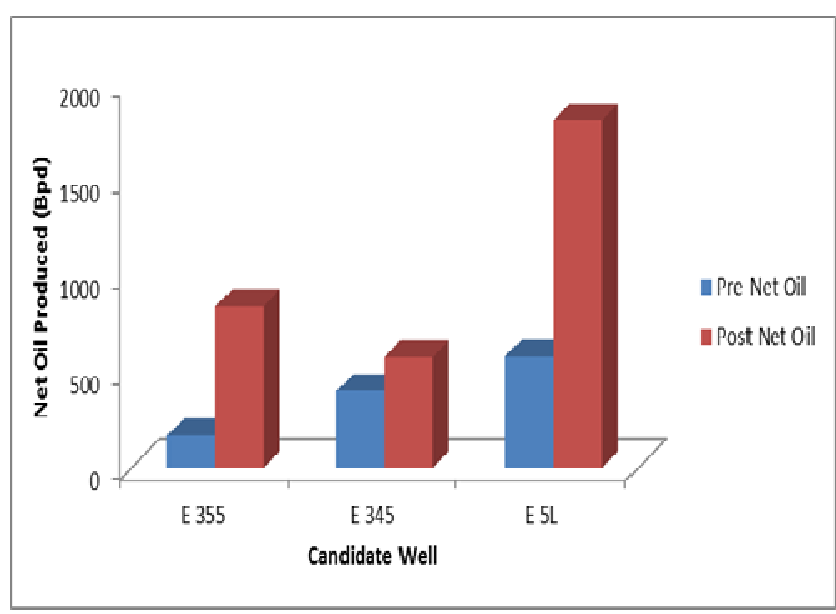

Figure 3. Net Oil produced before and after acid treatment.

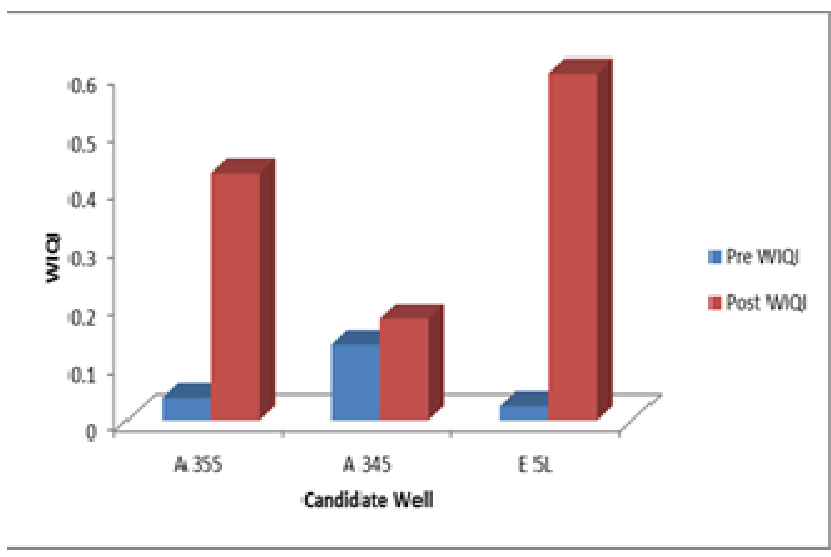

Figure 4. Well inflow quality indicator before and after acid treatment.

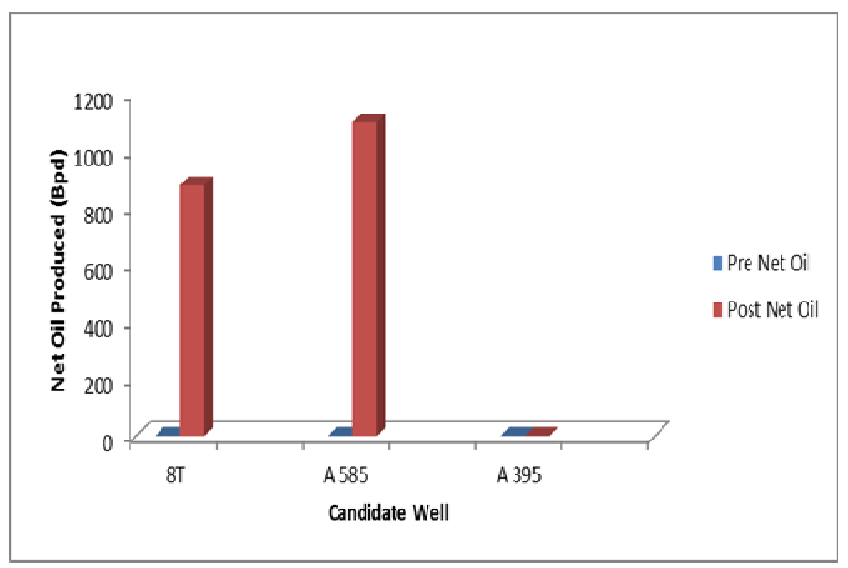

Figure 5. Net oil produced before and after acid treatment.

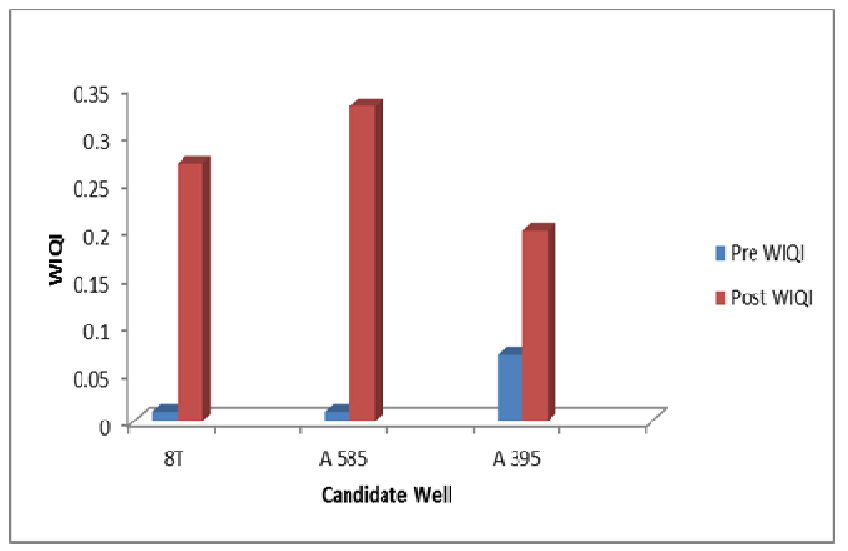

Figure 6. Well inflow quality indicator before and after acid treatment.

\section{Appendix II}

Table 4.1. Sandstone acid performance result for wells obign $2 t$, mini $2 t$ and mo-r $5 s$.

\begin{tabular}{|c|c|c|c|c|c|c|c|c|c|c|c|}
\hline Well \# & Choke/64 & $\begin{array}{l}\text { Pre-Net } \\
\text { Oil } \\
\text { (BOPD) }\end{array}$ & Pre-Date & $\begin{array}{l}\text { Post-Net } \\
\text { Oil } \\
\text { (BOPD) }\end{array}$ & Post Date & $\begin{array}{l}\text { Pre-ps } \\
\text { (psi) }\end{array}$ & $\begin{array}{l}\text { Post-psi } \\
\text { (psi) }\end{array}$ & $\begin{array}{l}\text { Pre- } \\
\text { WIQI }\end{array}$ & $\begin{array}{l}\text { Post } \\
\text { WIQI }\end{array}$ & $\begin{array}{l}\text { Pre } \\
\text { WHP }\end{array}$ & $\begin{array}{l}\text { Post } \\
\text { WHP }\end{array}$ \\
\hline Obign- $2 \mathrm{~T}$ & 72 & 633 & Nov 97 & 4780 & Mar 98 & 0.33 & 48.5 & 0.18 & 2.15 & 150 & 450 \\
\hline Mini-2T & 32 & 419 & Feb 98 & 1439 & Jun 98 & 0.47 & 7.20 & 0.017 & 0.3 & 334 & 550 \\
\hline Mo-R 5S & 32 & 201 & Apr 98 & 437 & Jun 98 & 0.19 & 8.8 & 0.01 & 0.3 & & \\
\hline
\end{tabular}


Table 4.2. sandstone acid performance result for wells agbada 8t, agbada 585 and agbada 395.

\begin{tabular}{llllllllllll}
\hline Well\# & $\begin{array}{l}\text { Choke } \\
\mathbf{6 4}\end{array}$ & $\begin{array}{l}\text { Pre-Net } \\
\text { Oil }\end{array}$ & $\begin{array}{l}\text { Post-dat } \\
\text { e }\end{array}$ & $\begin{array}{l}\text { Post- Net } \\
\text { oil } \\
\text { (BOPD) }\end{array}$ & $\begin{array}{l}\text { Post } \\
\text {-date }\end{array}$ & $\begin{array}{l}\text { Pre-pi } \\
\text { actual } \\
\text { (psi) }\end{array}$ & $\begin{array}{l}\text { Post pi } \\
\text { (psi) }\end{array}$ & $\begin{array}{l}\text { Pre- } \\
\text { WIPI }\end{array}$ & $\begin{array}{l}\text { Post } \\
\text { WIQI }\end{array}$ & $\begin{array}{l}\text { Pre-WH } \\
\text { P }\end{array}$ & $\begin{array}{l}\text { Post } \\
\text { WHP }\end{array}$ \\
\hline $\begin{array}{l}\text { AGBAD } \\
\text { A 8T }\end{array}$ & 20 & 1 & DEC 96 & 879 & MAR 98 & 0.7 & 8.6 & 0.01 & 0.27 & 88 & 35 \\
$\begin{array}{l}\text { AGBAD } \\
\begin{array}{l}\text { A 585 } \\
\text { AGBAD }\end{array}\end{array}$ & 24 & 1 & DEC 96 & 1100 & SEP 98 & 0.3 & 3.8 & 0.01 & 0.33 & 50 & 340 \\
A 395 & 24 & 1 & DEC 96 & 1 & SEP 98 & 0.0 & 0.0 & 0.07 & 0.2 & 80 & 120 \\
\hline
\end{tabular}

Table 4.3. sandston acid performance result (2002).

\begin{tabular}{|c|c|c|c|c|c|c|}
\hline \multirow{2}{*}{ CANDIDATE } & \multicolumn{2}{|c|}{ OIL RATE ( BOPD) } & \multicolumn{2}{|c|}{ WATER CUT (\%) } & \multicolumn{2}{|l|}{ SKIN sd } \\
\hline & BEFORE & AFTER & BEFORE & AFTER & BEFORE & AFTER \\
\hline Case 1 & 626 & 4226 & 5 & 0 & 405 & 0 \\
\hline Case 2 & 0 & 1,350 & 30 & 24 & 210 & 1 \\
\hline Case 3 & 0 & 490 & 53 & 45 & 433 & 2 \\
\hline Case 4 & 470 & 1470 & 55 & 48 & 187 & 20 \\
\hline Case 5 & 550 & 1690 & 50 & 53 & 430 & 28 \\
\hline Case 6 & 1200 & 2300 & 35 & 38 & 431 & 80 \\
\hline Case 7 & 0 & 650 & 25 & 0 & 24 & 12 \\
\hline Case 8 & 774 & 1050 & 20 & 22 & 160 & 50 \\
\hline Case 9 & 240 & 170 & 35 & 40 & 230 & 130 \\
\hline Case 10 & 1536 & 4210 & 0 & 0 & 180 & 0 \\
\hline
\end{tabular}

Table 4.4. Sandstone acid performance result for wells ekulama 355, ekulama 345 and okubie $5 l$.

\begin{tabular}{|c|c|c|c|c|c|c|c|c|c|c|c|}
\hline Well \# & $\begin{array}{l}\text { CHO } \\
\text { KE } 64 \\
\end{array}$ & $\begin{array}{l}\text { PRE- NET } \\
\text { OIL (BOPD) }\end{array}$ & $\begin{array}{l}\text { PRE- } \\
\text { DATE }\end{array}$ & $\begin{array}{l}\text { POST -NET OIL } \\
\text { (BOPD) }\end{array}$ & $\begin{array}{l}\text { POST } \\
\text { DATE }\end{array}$ & $\begin{array}{l}\text { POST } \\
\text { (PSI) }\end{array}$ & $\begin{array}{l}\text { POST } \\
\text { (PSI) }\end{array}$ & $\begin{array}{l}\text { PRE } \\
\text { WIQI }\end{array}$ & $\begin{array}{l}\text { POST } \\
\text { WIQI }\end{array}$ & $\begin{array}{l}\text { PRE } \\
\text { WHP }\end{array}$ & $\begin{array}{l}\text { POS } \\
\text { WHP }\end{array}$ \\
\hline $\begin{array}{l}\text { EKULAMA } \\
355\end{array}$ & 18 & 171 & $\begin{array}{l}\text { OCT } \\
98\end{array}$ & 842 & APR 97 & 0.3 & 58.33 & 0.04 & 0.427 & 1015 & 1290 \\
\hline $\begin{array}{l}\text { EKULAMA } \\
345\end{array}$ & 24 & 402 & $\begin{array}{l}\text { FEB } \\
96\end{array}$ & 577 & MAR 97 & 3.5 & 3.6 & 0.13 & O.176 & 120 & 150 \\
\hline OKUBIE 5L & 20 & 580 & FEB97 & 1812 & MAR 97 & 0.7 & 8.59 & 0.025 & 0.60 & 1640 & 2500 \\
\hline
\end{tabular}

Table 4.5. Sandstone acid performance analysis (2001-2002).

\begin{tabular}{lllllllll}
\hline Well \# & $\begin{array}{l}\text { Post-Net Oil } \\
\text { (BOPD) }\end{array}$ & $\begin{array}{l}\text { Pre-Net Oil } \\
\text { (BOPD) }\end{array}$ & $\begin{array}{l}\text { Increase oil } \\
\text { (BOPD) }\end{array}$ & $\begin{array}{l}\text { \% Increase } \\
\text { in Oil } \\
\text { (BOPD) }\end{array}$ & $\begin{array}{l}\text { Pre-WHP } \\
\text { Psi }\end{array}$ & $\begin{array}{l}\text { Post-WHP } \\
\text { Psi }\end{array}$ & $\begin{array}{l}\text { Increase in } \\
\text { Drawdown PSI }\end{array}$ & $\begin{array}{l}\text { \% Increase in } \\
\text { Drawdown Psi }\end{array}$ \\
\hline $\begin{array}{l}\text { EKULAMA } \\
\text { 355 }\end{array}$ & 845 & 171 & 674 & 79.6 & 1015 & 1290 & 275 & 21.3 \\
$\begin{array}{l}\text { EKULAMA } \\
\text { 345 }\end{array}$ & 577 & 402 & 175 & 43.5 & 120 & 150 & 30 & 20 \\
OKUBIE 3L & 1812 & 580 & 1232 & 212.4 & 1640 & 2500 & 860 & 34.4 \\
\hline
\end{tabular}

\section{References}

[1] F. Civan. "Reservoir Formation Damage: Fundamentals, Modelling, Assessment and Mitigation" $2^{\text {nd }}$ Edition, Gulf professional Publishing, Texas, USA 2000.

[2] A. Bale, M.B. Smith, and H.H. Klein, "Stimulation of Carbonates Combining Acid Fracture with Proppant (CAPF): A revolutionary Approach for Enhancement of Final Fracture Conductivity and Effective Half Length. Paper SPE 134307 Presented at the SPE Annual Technical Conference and Exhibition, Florence, Italy, 2010. http://dx.doi.org/ 102118/ 134307-MS
[3] F.F. Chang, H.A. Nasr-El-Din, T. Lindvig, and X.W. Qiu, "Matrix Acidizing of Carbonate Reservoirs using Organic Acids and Mixtures of HCL and Organic Acids, Paper SPE 1106601, Presented at the SPE Annual Technical Conference and Exhibition held in Denver, Colorado, 2008

[4] B.J. Patton, F. Pitts, T. Goeres, and G. Hertfelder, "Matrix Acidizing Case Studies for the point Arguello Field. In: SPE Western/AAPG Pacific Section Joint Meeting, 2003, pp.1-8

[5] T. Huang, L. Ostensen and A.D. Hill, "Carbonate Matrix Acidizing with Acetic Acid, Paper SPE 58715, 2000.

[6] B.Ugbenyen, D. Ogbe, and S. Osisanya, "Efficient Methodology for Stimulation Candidate Selection and Well Workover Optimization”. Society of Petroleum Engineers 2011, doi. 10.21181150780-MS 
[7] G. R. Coulter and A.R. Jenning, “ A Contemporary Approach to matrix Acidizing, Paper SPE 56279, 1999.

[8] D.B. Bennion, F.B. Thomas, D.W. Bennion and R.F. Bietz, Mechanism of Formation Damage and permeability impairment Associated with the Drilling, Completion and Production of Low API Gravity Oil, Reservoirs, Paper SPE 30320, doi:10.2118/30320-MS

[9] D.B. Bennion, F.B. Thomas, and D.A. Sheppard, Formation Damage Due to Mineral Alteration and Wettability Changes During hot Water and Steam Injection in Clay Bearing Sandstone Reservoirs. Society of Petroleum Engineers, doi: 10.2118/23783-MS. 1992.

[10] E. Nnanna and J.Ajienka, "Critical Success Factor for Well Stiulation”. Paper SPE 98823 2005, pp. 1-3.

[11] J.R. Jennings Jr., and G.J Lloyd, "Method of improving High Impulse Fracturing. U.S. Patent no. 4,807,702 1989.

[12] F.C. Okonkwo and M.O. Onyekonwu, "New Pseudo- Skin Model for Flow convergence to perforations in competent formations, Journal of Petroleum Science and Engineering vol. 17 no. 3. 1997.
[13] G. Nitter, L. Roodhart, H. Jongma, V. Yeager, M. Buijse, D. Fulton, and E. Jantz, Structured approach to Advanced Candidate Selection and Treatment Design of Stimulation Treatments. Paper SPE 63179, 2000.

[14] S. Morsy, J.J. Sheng, C.J. Hetherington, M. Soliman, and R. Ezewu Paper SPE 167568, 2013.

[15] M.L. Hofner, H.S. Fogler, P. Stenius and J. Sjoblom, "Role of Acid Diffusion in Matrix Acidizing of Carbonate". Journal of Petroleum Technology 39(02), 1987, 203-208.

[16] M. Dehgani, "Matrix Acid Stimulation" The First International Geological Congress, Department of Geology, Islamic Azad University, 2010.

[17] T. Ahmed, "Reservoir Engineering Handbook" Gulf professional Publishing, 2001, pp. 473-474.

[18] C. Ibelegbu, "Productivity Index in Horizontal Well" Journal of Scientific and Industrial Research vol. 63, 2004, pp. 979-984. 